\title{
Effects of fertilizers and arbuscular mycorrhizal fungi on the post-vitro growth of micropropagated strawberry
}

\author{
SCK Williams 1, M Vestberg 2, M Uosukainen 2, JC Dodd 2, P Jeffries ${ }^{\text {* }}$ \\ ${ }^{1}$ The University of Kent, Biological Laboratory, Canterbury, Kent, CT2 7NJ, UK; \\ 2 Agricultural Research, Centre of Finland, Laukaa Research and Elite Plant Unit, Juntula, SF-41340 Laukaa, Finland \\ ${ }^{3}$ Durrell Institute of Conservation and Ecology, The University of Kent, UK
}

(COST Meeting, 21-23 May 1992, Dijon, France)

\begin{abstract}
Summary - A 5-wk factorial experiment was conducted to examine the effects of osmocote (18N:11P:10K; commercial controlled-release fertilizer), rock phosphate and 3 species of arbuscular mycorrhizal fungi on the growth of the strawberry cultivar Senga Sengana in a peat-sand-vermiculite substrate. Three Glomus species, G98 (probably $G$ intraradices), G128 (an undescribed species) and $G$ geosporum were compared. G98 and G128 significantly increased shoot dry weights compared with the non-mycorrhizal control. Levels of root colonization by G98 and G128 were significantly greater than by $G$ geosporum. The addition of both fertilizer types significantly increased shoot dry weights. Neither osmocote $(0.5-2.0 \mathrm{~g} / \mathrm{l})$ nor rock phosphate $(1.0-5.0 \mathrm{~g} / \mathrm{l})$ addition had a significant effect on colonization by the 3 fungi. An osmocote fertilizer applied at $25 \%$ of the minimum recommended commercial rate to mycorrhizal plants was sufficient to produce equivalent dry matter yields as non-mycorrhizal plants receiving the full application of osmocote. All 3 fungal species significantly increased the stolon number per plant when compared with the non-mycorrhizal controls. Results clearly show that healthy mycorrhizal strawberry plants can be produced at weaning using commercial or reduced rates of osmocote or a rock phosphate formulation.
\end{abstract}

phosphate / fertilizer / arbuscular mycorrhizal fungus / strawberry / micropropagation

Résumé - Effet d'engrais et de champignons mycorhiziens arbusculaires sur la croissance post-vitro de fraisiers micropropagés. Un essai factoriel de 5 semaines a été fait pour examiner les effets de l'osmocote, (engrais commercial à diffusion contrôlée 18:11:10), du phosphate naturel, et de 3 espèces de champignons AM sur la croissance du cultivar de fraisier Senga Sengana sur un substrat tourbe : sable : vermiculite. On a comparé 3 espèces de Glomus G98 (probablement G intradices), G128 (espèce non décrite), et de G geosporum. G98 et G128 ont augmenté significativement les poids sec de tiges, par rapport aux témoins non inoculés. Les niveaux de colonisation des racines par G98 et G128 étaient plus élevés que celui de G geosporum. L'addition des 2 engrais a significativement augmenté le poids sec des tiges. Ils n'ont aucun effet sur la colonisation par les 3 champignons. L'osmocote appliqué à $25 \%$ de la dose minimale conseillée commercialement suffit pour produire les mêmes rendements en matière sèche sur les plantes mycorhizées que la dose complète sur les témoins non mycorhizés. Les 3 espèces de champignon augmentent significativement le nombre de stolons par plante, par rapport au témoin. Les résultats montrent clairement que l'on peut produire des plantes mycorhizées saines de fraisier au sevrage en utilisant des doses commerciales ou réduites d'osmocote ou de phosphate naturel.

phosphate / engrais / champignon mycorhizien arbusculaire / fraisier / micropropagation

\footnotetext{
* Correspondence and reprints
} 


\section{INTRODUCTION}

Strawberry production in the UK involves outplanting of nursery plants, usually into soils sterilized with methyl bromide and/or chloropicrin to control root diseases such as Verticillium wilt, and red core caused by Phytophthora fragariae (Wilhelm and Paulus, 1980). Unfortunately, soil fumigation also eliminates any indigenous arbuscular mycorrhizal fungi (AMF) which are of vital importance for efficient uptake of nutrients, especially phosphorus $(P)$, by plants growing in many natural and agricultural ecosystems (Krikun et al, 1990).

The presence of mycorrhizal fungi in strawberry planting material has been implicated in a significant increase in fruit production in a fumigated field (Robertson et al, 1988) and in increases in dry weight following inoculation with mycorrhizal fungi (Holevas, 1966; Koomen et al, 1987). More recently Hrselova et al (1989) demonstrated a $17 \%$ increase in stolon length and increased $\mathrm{P}$ content in all plant parts in strawberry plants colonized by AMF. Dunne and Fitter (1989) demonstrated that the P-inflow during strawberry flower and fruit development exceeded the calculated maximum potential inflow via both the old and the new roots. They concluded, therefore, that this excess $P$ requirement could only be met if nutrient uptake was assisted by AMF.

Field inoculation of crop plants, however, is impractical due to the technical difficulties and the large amount of inoculum required. Inoculation of the nursery plant may be an alternative strategy for improving plant growth (Gianinazzi et al, 1989). In both the UK and in Finland, many varieties of strawberry are micropropagated prior to planting in the propagation beds. Inoculation of micropropagated strawberry with AMF has increased plant height at weaning by up to $343 \%$ (Chavez and Ferrera-Cerrato, 1987). Kiernan et al (1984) showed that strawberry tissue-cultured plants increased their shoot growth in a peatperlite substrate when inoculated with 2 Glomus species. As plant death is often a problem when weaning micropropagated material there is also potential for increasing survival rates and for controlling root pathogens (Caron, 1989).

This study was aimed at integrating the use of AMF into strawberry plant weaning by adapting current techniques to produce healthy mycorrhi- zal planting material. The effect of 2 different fertilizers on plant and mycorrhizal development during the plant weaning stage was examined. It was intended to find a fertilizer regime which would permit good mycorrhizal colonization and promote efficient plant growth while comparing 3 AMF species, 2 from Finland with 1 from the UK. With the increasing interest in reducing chemical/ inorganic fertilizer inputs, techniques for reintroducing these beneficial fungi into strawberry production, at appropriate fertilizer levels, requires investigation.

\section{MATERIALS AND METHODS}

\section{Plant material}

In vitro strawberry plants (Fragaria $\mathrm{x}$ ananassa Duch cv Senga Sengana) were propagated on a modified Boxus agar medium (Boxus, 1974). They were transferred to rooting medium for 4 wk prior to being transplanted into the experimental substrata. In an earlier comparison of substrata mixes (data not presented), it was found that although high levels of mycorrhizal root colonization occurred in all substratum types, only peat-sand-vermiculite (8:1:1; v:v:v) supported good plant growth. A standard plant growth substratum of peat-sand-vermiculite $(8: 1: 1 ; \mathrm{v}: \mathrm{v}: \mathrm{v})$, with the addition of $10 \mathrm{~g} / \mathrm{l}$ dolomite lime to adjust $\mathrm{pH}$ to 5.5 , was thus used for all treatments.

\section{Mycorrhizal fungi}

More than 80 AMF have been isolated into pure pot culture from various locations around Finland (Vestberg, unpublished data). This collection had been screened for induction of a beneficial growth response in the strawberry cultivar under test and 2 Finnish species were selected which gave the best growth response. G98 was isolated from a grassland with sandy soil, pH 5.35, from western Finland. It has been tentatively identified as Glomus intraradices. G128 was isolated from a grassland with sandy soil, $\mathrm{pH} 5.40$, from central Finland. It is similar to $G$ maculosum but is probably a new species (Walker, personal communication). A third species, $G$ geosporum (from under wheat in an agricultural soil in Kent, southeast England, $\mathrm{pH} 7.2$ ), was chosen as a broad range species for comparison in this experiment. The inoculum was prepared from pure pot-cultures and consisted of finely chopped root fragments, and pot-culture substratum (peat-sand-vermiculite; $8: 1: 1$; v:v:v) containing extraradical spores and mycelium. 


\section{Fertilizer treatments}

Two sources of $P$ were compared: i) rock phosphate $(16 \% \mathrm{P})$, a slow P-releasing fertilizer, known to promote good mycorrhizal development and healthy plant growth (Sieverding, 1991); and ii) osmocote (8-9 month, $18 \mathrm{~N}: 11 \mathrm{P}: 10 \mathrm{~K}$, Sierra UK Ltd), a commercially available controlled-release fertilizer. Each fertilizer type was applied at 4 levels: osmocote at $0,0.5,1.0$ and $2.0 \mathrm{~g} / \mathrm{l}$ and rock phosphate at $0,1.0,3.0$ and $5.0 \mathrm{~g} /$ I. Rock phosphate treatments had an additional 846 $\mathrm{mg} / \mathrm{NK}$ micronutrient fertilizer (Kemira Oy, Finland, containing: $13 \% \mathrm{~N} ; 13 \% \mathrm{~N} ; 9.2 \% \mathrm{~S} ; 3.4 \% \mathrm{Ca} ; 3.0 \%$ $\mathrm{Mg} ; 0.15 \% \mathrm{~B} ; 0.1 \% \mathrm{Cu} ; 0.7 \% \mathrm{Mn} ; 0.1 \% \mathrm{Zn}$ ) to avoid any possibility of nutrient deficiency. All media were hand-mixed for 10 min to ensure an even distribution of all constituents.

\section{Experimental details}

Four mycorrhizal treatments were compared: i) control (no AMF); ii) inoculation with $G$ geosporum; iii) inoculation with G98; and iv) inoculation with G128. The control inoculum consisted of a mixture of inoculum of all 3 AMF autoclaved 3 times for $20 \mathrm{~min}$. Washings of fresh AMF inoculum were used for the initial watering of the control treatment to ensure that a similar bacterial population was applied to all treatments.

The substrata were placed in 250-ml square plastic pots, watered and allowed to equilibrate for $24 \mathrm{~h}$ before adding $2.5 \mathrm{~g}$ mycorrhizal inoculum to each planting hole. Treatments were replicated 6 times and arranged in a randomized complete block design. Plants were removed from their in vitro containers, the agar removed with water, and planted. For the first $5 \mathrm{~d}$ plants were covered with a double layer of "frost protection" fibre cloth to maintain a high humidity, and for the first 2 wh sprayed when necessary with water. Guard plants were arranged around the perimeter of the experimental layout. Plants were raised in a growth chamber with $70 \%$ humidity for the first 2 wk, and $50 \%$ for the remaining 3 wk. A 16-photoperiod of 205-273 $\mu \mathrm{mol} \mathrm{m} \mathrm{m}^{-2} \mathrm{~s}^{-1}$ photosynthetic active radiation was supplied by $58 \mathrm{~W}$ warm white super fluorescent tubes. A mean temperature of $22{ }^{\circ} \mathrm{C}$ was maintained throughout the experiment.

After 5 wk all plants were placed at $4^{\circ} \mathrm{C}$. Shoot and root fresh and dry weights $\left(60^{\circ} \mathrm{C}\right.$ for $\left.24 \mathrm{~h}\right)$ were recorded. Roots were cleared and stained in $0.05 \%$ trypan blue in acidified glycerol (modified from Phillips and Hayman, 1970) and AMF colonization determined under the steromicroscope $(x 20)$ using a grid-line intersect method (Giovanetti and Mosse, 1980). Samples in which root colonization was difficult to quantify due to poor staining were mounted on a slide for more detailed observation under the compound microscope $(x 400)$.

\section{Statistical treatment}

The experiment was set up in a randomized complete block design and was statistically analyzed as a factorial. Data were subjected to analysis of variance using Genstat 5 (Rothamsted Experimental Station, Harpenden, UK). The statistical significance of differences between means was determined using the least significant difference (LSD) at $P=0.05$ (Steel and Torrie, 1960).

\section{RESULTS}

The percentage root colonization by both $\mathrm{G} 98$ and G128 within the 5-wk time period was significantly greater than for $G$ geosporum (table I). Approximately half of the root system had been colonized by these 2 isolates at the end of the experiment whereas only $25 \%$ of the root system was colonized by $G$ geosporum. The type and amount of fertilizer did not affect the relative amount of root colonization (table II).

Microscopic observation of roots revealed differences in the staining of fungal structures depending on the AMF used. In roots of plants inoculated with $G$ geosporum typical AMF vesicles and arbuscules could be clearly observed. No intraradical colonization was discernable in roots of plants inoculated with G98 and G128, when examined under the stereomicroscope, even though stained extraradical mycelium, appressoria and spores were clearly visible. More detailed inspection of these roots under a compound microscope, however, revealed that

Table I. Mean percentage root colonization of plants after 5 wk growth colonized by 3 arbuscular mycorrhizal fungi under 2 fertilizer regimes. Data for all osmocote and rock $P$ treatments combined.

\begin{tabular}{lccc} 
Fertilizer & \multicolumn{3}{c}{ Arbuscular mycorrhizal fungi } \\
& G geosporum & G98 & 28 \\
& & & \\
Osmocote & 23 & $46^{*}$ & $52^{\star}$ \\
Rock P & 28 & $48^{\star}$ & $53^{\star}$
\end{tabular}

\footnotetext{
* Significant different from $G$ geosporum within fertilizer treatments at $P=0.05$ (LSD values for osmocote $=8$ and for rock phosphate $=7$ ).
} 
Table II. Mean percentage arbuscular mycorrhizal root colonization of plants after 5 wk growth given different levels of fertilizer. Data for all fungal inoculations combined.

\begin{tabular}{|c|c|c|c|c|c|c|}
\hline \multirow{2}{*}{$\begin{array}{l}\text { No } P \\
\text { control }\end{array}$} & \multicolumn{3}{|c|}{ Osmocote } & \multicolumn{3}{|c|}{ Rock $P$} \\
\hline & $0.5 \mathrm{~g} / \mathrm{l}$ & $1.0 \mathrm{~g}$ & $2.0 \mathrm{~g} / \mathrm{l}$ & 1.09 & $3.0 \mathrm{~g}$ & $5.0 \mathrm{~g} /$ \\
\hline 44 & 36 & 41 & 41 & 40 & 43 & 44 \\
\hline
\end{tabular}

unstained vesicles and fungal mycelium containing characteristic lipid droplets were present inside the roots. Larger vesicles of G98 and G128 did, however, stain effectively and could be clearly seen with stereomicroscope. In the results reported here, levels of colonization for G98 and G128 have been determined from a combination of low and high-power microscope examination.

Table III shows the effects of combinations of AMF and fertilizer on the shoot dry weights of plants at harvest. Plants colonized by G98 and G128 and receiving osmocote fertilizer showed significant increases in dry weight compared with non-mycorrhizal plants. Plants colonized by $G$ geosporum and supplied with osmocote fertilizer also out-yielded non-mycorrhizal plants but this was not quite significant at the $P=0.05$ level. Shoot dry weights of plants receiving rock phosphate fertilizer were not increased significantly by colonization with any of the AMF (table III).

Table III. Mean shoot dry weights (mg) of plants after 5 wk growth colonized with 3 arbuscular mycorrhizal fungi under 2 fertilizer regimes. Data for all osmocote and rock $P$ treatments combined.

Fertilizer Uninoculated Arbuscular mycorrhizal fungi control

G geosporum G98 G128

\begin{tabular}{lllll}
\hline & & & & \\
Osmocote & 505 & 637 & $741^{\star}$ & $700^{\star}$ \\
Rock P & 580 & 593 & 681 & 664 \\
\hline
\end{tabular}

* Significant difference from the control within fertilizer treatments at $P=0.05$ (LSD values for osmocote $=137$ and for rock phosphate $=132$ ).
Table IV shows that addition of osmocote or rock phosphate significantly increased the shoot dry weight of strawberry plants. Increasing the amount of osmocote added, however, from $0.5 \mathrm{~g} /$ $\mathrm{I}-2.0 \mathrm{~g} / \mathrm{l}$ or rock phosphate from $1.0 \mathrm{~g} / \mathrm{l}$ to $5.0 \mathrm{~g} / \mathrm{l}$, did not result in any significant increases in plant size. In a more detailed analysis of the combined data for all mycorrhizal plants, when compared with their non-mycorrhizal counterparts, further differences were noted. Figure 1 shows the comparative shoot yields of plants receiving different amounts of osmocote fertilizer. For the nonmycorrhizal plants, the shoot dry weight increased proportionally with the amount of osmocote added. For mycorrhizal plants, however, the shoot dry weight of plants had reached a plateau at the lowest rate of osmocote applied, and this maximum yield was sustained across all concentrations of osmocote used. Even at the highest rate of osmocote used $(2.0 \mathrm{~g} / \mathrm{l}$, which is equivalent to the minimum recommended commercial rate), the mycorrhizal plants outyielded the nonmycorrhizal plants, although this was not significant $(P=0.05)$.

All 3 AMF significantly increased the stolon number of plants receiving osmocote fertilizer but had no significant effect on stolon number when plants received rock phosphate (table V). Addition of both fertilizer types significantly increased stolon number compared with the control (table VI).

\section{DISCUSSION AND CONCLUSION}

The aim of this study was to find an optimum level of fertilizer which would allow good coloniza-

Table IV. Mean shoot dry weights (mg) of plants after 5 wk growth given different amounts of fertilizer. Data for all fungal inoculations combined.

\begin{tabular}{llllll}
$\begin{array}{l}\text { No } P \\
\text { control }\end{array}$ & \multicolumn{2}{c}{ Osmocote } & & \multicolumn{2}{c}{ Rock $P$} \\
\hline $0.5 \mathrm{~g} / \mathrm{l} 1.0 \mathrm{~g} / \mathrm{ll} 2.0 \mathrm{~g} / \mathrm{l}$ & & $1.0 \mathrm{~g} / \mathrm{ll} 3.0 \mathrm{~g} / \mathrm{l} 5.0 \mathrm{~g} / \mathrm{l}$
\end{tabular}

* Significant difference from the control within fertilizer treatments at $P=0.05$ (LSD values for osmocote $=137$ and for rock phosphate $=132$ ) 


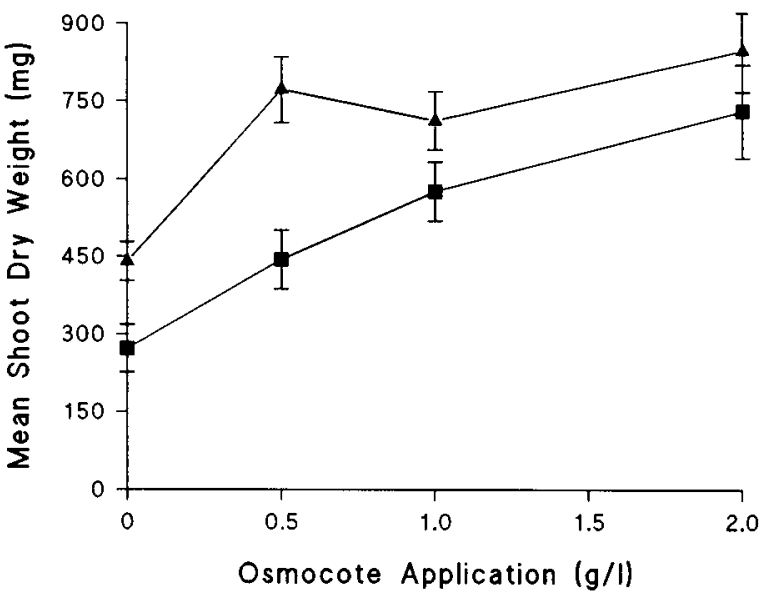

Fig 1. Mean shoot dry weight of mycorrhizal $(\mathbf{A})$ and nonmycorrhizal ( $\mathbf{\square})$ strawberry plants, after 5 wk growth, given different amounts of osmocote. Data for all 3 mycorrhizal treatments combined (error bars = standard error of treatment means).

tion by AMF while stimulating healthy plant growth acceptable to the strawberry industry. We have shown that mycorrhizal colonization take place within the root system of strawberry plants receiving commercial rates of phosphorus fertilizers and that this results in improved growth. Furthermore, we have shown that fertilizer inputs can be reduced in mycorrhizal plants to levels considerably lower than those used in commercial practice and yet plant development can be maintained that is equivalent to that of nonmycorrhizal plants receiving full fertilizer inputs.

In these experiments it was noted that all 3 AMF did not colonize to roots to the same extent. G98 and G128 colonized more of the root system than $G$ geosporum. Fertilizer application did not

Table V. Mean number of stolons per plant after 5 wk growth colonized by 3 arbuscular mycorrhizal fungi under 2 fertilizer regimes. Data for all osmocote and rock $P$ treatments combined.

\begin{tabular}{lcccc} 
Fertilizer $\begin{array}{c}\text { Uninoculated } \\
\text { control }\end{array}$ & \multicolumn{4}{c}{ Arbuscular mycorrhizal fungi } \\
\cline { 3 - 5 } & & G geosporum & G98 & G128 \\
\hline & & & & \\
Osmocote & 0.5 & $1.0^{*}$ & $1.0^{*}$ & $1.0^{*}$ \\
Rock P & 0.8 & 0.8 & 1.2 & 1.0 \\
\hline
\end{tabular}

\footnotetext{
* Significant difference from the control within fertilizer treatments at $P=0.05$ (LSD values for osmocote $=0.4$ and for rock phosphate $=0.5$ ).
}

significantly decrease levels of colonization but plants colonized by $G 98$ and $\mathrm{G} 128$ were significantly larger than those colonized by $G$ geosporum. The improved growth of plants obtained following inoculation with G98 and G128 could have been due to either the higher levels of colonization or to differences in AM fungal efficiency in transporting $P$ and other nutrients to the host plant. There was, however, no significant correlation between the percentage root colonization and shoot dry weight (data not shown). This indicates that the increased growth of shoots was probably related to the greater effectiveness of G98 and G128 in supplying the host plant with nutrients under these conditions. Differences in the ability of AMF to extract nutrients from the soil solution and to release them to the plant have been reported in the literature (Hayman and Tavares, 1985; Sieverding, 1991). Chavez and Ferrera-Cerrato (1990) measured the responses of 4 micropropagated strawberry cultivars to root colonization by AMF. They found that plant yields differed significantly depending on the AMF used and that yield was unrelated to percentage root colonization. Some plant cultivar/fungal combinations resulted in improved plant growth while others did not. Our results were similar and suggest that $G$ geosporum would be the least suitable of the 3 AMF tested for integration into strawberry production under the conditions used. This is not surprising given the fact that G98 and G128 were chosen on the basis of a preliminary screening programme.

The $\mathrm{pH}$ of the growth substratum is an important parameter affecting mycorrhizal efficiency and could also explain the varying abilities of the 3 AMF used in this experiment to stimulate a plant growth response. $G$ geosporum was isolated from a Kent soil of $\mathrm{pH} 7.2$, whereas the Finn-

Table VI. Mean number of stolons per plant after 5 wk growth given different amounts of fertilizer. Data for all fungal inoculations combined.

\begin{tabular}{llllllll}
$\begin{array}{l}\text { No } P \\
\text { control }\end{array}$ & \multicolumn{2}{c}{ Osmocote } & & \multicolumn{3}{c}{ Rock $P$} \\
\hline $0.5 \mathrm{~g} / \mathrm{l} 1.0 \mathrm{~g} / \mathrm{l} 2.0 \mathrm{~g} / \mathrm{l}$ & & & $1.0 \mathrm{~g} / \mathrm{l} 3.0 \mathrm{~g} / \mathrm{l} 5.0 \mathrm{~g} / \mathrm{l}$ \\
\hline 0.2 & $1.0^{*}$ & $0.9^{*}$ & $1.4^{*}$ & & $1.1^{*}$ & $1.2^{*}$ & $1.3^{*}$
\end{tabular}

\footnotetext{
* Significant difference from the control within fertilizer treatments at $P=0.05$ (LSD values for osmocote $=0.4$ and for rock phosphate $=0.5$ ).
} 
ish AMF were isolated from and maintained in substratum with a pH of $\approx 5.5$. A substratum $\mathrm{pH}$ of 5.8 is optimum for strawberry plant growth (Lineberry, 1935) and the $\mathrm{pH}$ of the plant growth medium used in this experiment was 5.5. It may well have been unsuitable for the effective functioning of a $G$ geosporum mycorrhiza. The effect of $\mathrm{pH}$ on the effectivity of different AMF has been noted by other workers. For example, Hayman and Tavares (1985) showed that the effectiveness of Acaulospora laevis in stimulating growth of alpine strawberry was reduced $>\mathrm{pH} 6$, in contrast to Glomus fasiculatum, the effectiveness of which decreased gradually with increasing $\mathrm{pH}$.

Differences in the ability of AMF to colonize root systems, the "colonization capacity" (Tommerup, 1992), may also have played a part in the lower percentage root colonization observed with $G$ geosporum. By adjusting the quantity of inoculum added for each AMF, similar colonization levels might have been obtained by the end of the 5wk experimental period. Differences in percentage root colonization could also have been due to problems experienced in the staining of fungal structures of G98 and G128 inside the roots. Merryweather and Fitter (1991) reported a similar problem in bluebells and suggested that non- or poorly-staining AMF are common in natural soils and that this has led to a gross underestimation of AMF colonization levels in previously published work. In such cases it is necessary to use the compound microscope to assess the presence of AMF in root systems (Dodd and Jeffries, 1986).

The addition of osmocote controlled-release fertilizer and rock phosphate significantly increase plant dry matter production, and this effect was enhanced when AMF were present. Increased amounts of applied fertilizer had no effect on root colonization by G98 and G128. Other workers have also reported the integration of controlled release fertilizers with AMF inoculation. Davies (1987) showed that an equivalent growth of Rosa multiflora, inoculated with 2 Glomus species in a composted bark-sand substrate, could be obtained using $29 \%$ of the recommended rate of osmocote (18 N:6 P:12 K). Our data show that mycorrhizal plants receiving $25 \%$ of the minimum recommended commercial rate of osmocote had a similar yield to nonmycorrhizal plants which received the full recommended rate of this fertilizer. Waterer and Coltman (1988) used osmocote (19 N:2.6 P:10 K) to produce mycorrhizal and non-mycorrhizal transplants of pepper and leek in a peat-vermiculite $(1: 1 ; v: v)$ medium. They concluded that it was possible to maintain significant mycorrhizal colonization in transplants given enough controlledrelease $\mathrm{P}$ to be horticulturally acceptable. Our results confirm this finding as we also maintained high levels of AMF root colonization in plants supplied with the commercial rates of fertilizer commonly used in Finland and in the UK. Our results have also shown that mycorrhizal plants produced more stolons per plant within the experimental period. There could be several explanations for these observations, such as improved nutritional status or alterations in hormonal balance, but we do not have the data to interpret this effect in any more detail.

In conclusion, great potential exists for using AMF by the horticultural industry when used in combination with reduced quantities of an appropriate fertilizer. The field performance of this planting material compared with non-mycorrhizal material remains to be determined.

\section{ACKNOWLEDGMENTS}

The authors wish to thank the EC and SERC for financing exchanges between the 2 collaborating laboratories under the COST ACTION 8.10 programme. SCKW also thanks the SERC, Saphir Produce and Darby Bros (Farms) Ltd for financing his studentship. $J C D$ is funded by the Baring Foundation.

\section{REFERENCES}

Boxus $P$ (1974) Production of strawberry plants by in vitro micropropagation. J Hortic Sci 49, 209-210

Caron M (1989) Potential use of mycorrhizae in control of soil-borne diseases. Can J Plant Pathol 11, 177-179

Chavez MCG, Ferrara-Cerrato R (1987) Effect of captan and (V-A) endomycorrhiza on in vitro cultivated strawberry development. Rev Latinoam Microbiol 29, 193-199

Chavez MCG, Ferrera-Cerrato R (1990) Effect of vesicular arbuscular mycorrhizae on tissue culturederived plantlets of strawberry. Hortsci 25, 903-905

Davies FT Jr (1987) Effects of VA-mycorrhizal fungi on growth and nutrient uptake of cuttings of Rosa multiflora in two container media with three levels of fertilizer application. Plant Soil 104, 31-35

Dodd JC, Jeffries P (1986) Early development of vesicular-arbuscular mycorrhizas in autumn-sown cereals. Soil Biol Biochem 18, 149-154

Dunne MJ, Fitter AH (1989) The phosphorus budget of a field grown strawberry (Fragaria $\mathrm{x}$ ananassa cv Hapil) crop: evidence for a mycorrhizal contribution. Ann Appl Biol 114, 185-193 
Gianinazzi S, Gianinazzi-Pearson V, Trouvelot A (1989) Potentialities and procedures for the use of endomycorrhizas with special emphasis on high value crops. In: Biotechnology of Fungi for Improving Plant Growth (Whipps, JM, Lumdsen RD, eds) Cambridge University Press, Cambridge, UK, 41-45

Giovannetti M, Mosse B (1980) An evaluation of techniques for measuring vesicular arbuscular mycorrhizal infection in roots. New Phytol 84, 489-500

Hayman DS, Tavares M (1985) Plant growth responses to vesicular arbuscular mycorrhiza. XV. Influence of soil pH on the symbiotic efficiency of different endophytes. New Phytol 100, 367-377

Holevas CD (1966) The effect of a vesicular arbuscular mycorrhiza on the uptake of soil phosphorus by strawberry (Fragaria sp var Cambridge Favourite). $J$ Hortic Sci 41, 57-64

Hrselova H, Gryndler M, Vancura V (1989) Influence of inoculation with VA mycorrhizal fungus Glomus $\mathrm{sp}$ on growth of strawberries and runner formation. $\mathrm{Ag}$ ric Ecosyst \& Environ 29, 193-197

Kiernam JM, Hendrix JW, Soltz LP, Maronek DM (1984) Characterization of strawberry plants produced by tissue culture and infected with specific mycorrhizal fungi. Hortsci $19,883-885$

Koomen I, Grace C, Hayman DS (1987) Effectiveness of single and multiple mycorrhizal inocula on growth of clover and strawberry plants at two soil pHs. Soil Biol Biochem 19, 539-544

Krikun J, Hass JH, Dodd JC, Kinsbursky R (1990) Mycorrhizal dependence of four crops in a P-sorbing soil. Plant Soil 122, 213-217
Lineberry RA (1935) The relation of fertilizer and soil reaction to viability and production of strawberries. Comm Fertil 50, 12-16

Merryweather JW, Fitter AH (1991) A modified method for elucidating the structure of the fungal partner in a vesicular arbuscular mycorrhiza. Mycol Res $95,1435-1437$

Phillips JM, Hayman DS (1970) Improved procedures for clearing and staining parasitic and vesicular arbuscular mycorrhizal fungi for rapid assessment of infection. Trans Br Mycol Soc 55, 158-161

Robertson WJ, Boyle CD, Brown HL (1988) Endomycorrhizal status of certified strawberry nursery stock. J Am Soc Hortic Sci 113, 525-529

Sieverding E (1991) Vesicular Arbuscular Mycorrhizal Management in Tropical Agrosystems. Deutsche Gesellschaft fur Technische Zusammenarbeit (GTZ) GmbH Eschborn, Germany, $371 \mathrm{p}$

Steel RGO, Torrie JH (1960) Principles and Procedures of Statistics. McGraw-Hille, NY

Tommerup IC (1992) Methods for the study of the population biology of vesicular-arbuscular mycorrhizal fungi. In: Methods in Microbiology (Norris JR, Read DJ, Varma AK, eds) Academic Press, London, 24, 23-51

Waterer DR, Coltman RR (1988) Effects of controlled release phosphorus and inoculum density on the growth and mycorrhizal infection of pepper and leek transplants. Hortsci 23, 620-622

Wilhelm S, Paulus AO (1980) How soil fumigation benefits the California strawberry industry. Plant Dis 64, 264-270 